\title{
Article \\ Mid-Term Effects of Conservative Soil Management and Fruit-Zone Early Leaf Removal Treatments on the Performance of Nerello Mascalese (Vitis vinifera L.) Grapes on Mount Etna (Southern Italy)
}

\author{
Elisabetta Nicolosi $^{1}{ }^{(\mathbb{D}}$, Valeria Iovino ${ }^{2}$, Gaetano Distefano $^{1}{ }^{\mathbb{D}}$, Mario Di Guardo ${ }^{1} \mathbb{D}$, Stefano La Malfa $^{1}$, \\ Alessandra Gentile ${ }^{1}$, Alberto Palliotti ${ }^{3}$, Giuseppina Las Casas ${ }^{2}$ and Filippo Ferlito ${ }^{2, *(D)}$ \\ 1 Department of Agriculture, Food and Environment (Di3A), University of Catania, Via Valdisavoia 5, \\ 95123 Catania, Italy; elisabetta.nicolosi@unict.it (E.N.); gaetano.distefano@unict.it (G.D.); \\ mario.diguardo@unict.it (M.D.G.); stefano.lamalfa@unict.it (S.L.M.); alessandra.gentile@unict.it (A.G.) \\ 2 CREA, Research Centre for Olive, Fruit and Citrus Crops, Corso Savoia 190, 95024 Acireale, Italy; \\ iovino.valeri@gmail.com (V.I.); giuseppina.lascasas@crea.gov.it (G.L.C.) \\ 3 Department of Agricultural, Food and Environmental Sciences (DSA3), University of Perugia, \\ Borgo XX Giugno 74, 06121 Perugia, Italy; alberto.palliotti@unipg.it (A.P.) \\ * Correspondence: filippo.ferlito@crea.gov.it; Tel.: +39-095-765-3106
}

check for updates

Citation: Nicolosi, E.; Iovino, V.; Distefano, G.; Di Guardo, M.; La Malfa, S.; Gentile, A.; Palliotti, A.; Las Casas, G.; Ferlito, F. Mid-Term Effects of Conservative Soil Management and Fruit-Zone Early Leaf Removal Treatments on the Performance of Nerello Mascalese (Vitis vinifera L.) Grapes on Mount Etna (Southern Italy). Agronomy 2021, 11, 1070. https://doi.org/10.3390/ agronomy 11061070

Academic Editor: Dugald C. Close

Received: 1 April 2021

Accepted: 24 May 2021

Published: 26 May 2021

Publisher's Note: MDPI stays neutral with regard to jurisdictional claims in published maps and institutional affiliations.

Copyright: (c) 2021 by the authors. Licensee MDPI, Basel, Switzerland. This article is an open access article distributed under the terms and conditions of the Creative Commons Attribution (CC BY) license (https:/ / creativecommons.org/licenses/by/ $4.0 /)$.

\begin{abstract}
The aim of this study was to analyze the mid-term influence of minimum tillage (MT) combined with early leaf removal (ELR) on the performance of the black grapevine variety Nerello Mascalese (Vitis vinifera L.). The research was carried out from 2015 to 2018 in a vineyard located in the Mount Etna area, East Sicily, Southern Italy. An average of about $8000 \mathrm{~cm}^{2}$ of leaves were removed from the ELR vines, corresponding to a canopy defoliation of $44 \%$ in 2017 and 30\% in 2018. As for the stem water potential of both primary and lateral leaves, ELR-MT treatment showed the best performance (up to $-0.4 \mathrm{MPa}$ ) among the four combinations. In 2017, no differences in yield/vine were found among treatments, whereas in 2018 the yield was significantly lower in ELR treatments. Among the different treatments performed, the ELR-MT showed the best results both in terms of physiological plant parameters (water status and photosynthetic activity) and fruit quality (higher concentration of sugars and total anthocyanins and polyphenols). ELR-MT treatment is also associated with a lower incidence of tillage operations from four to only one per year $(-60-70 \mathrm{~h} / \mathrm{ha})$. In contrast to what was observed in the first 3 years of application (i.e., from 2015 to 2017), yield was heavily penalized during the fourth year of application (2018), probably due to the excessive depletion of nutritional reserves, the reduction of bud fertility and the unfavorable meteorological condition. For these reasons, the ELR-MT combination might require an interruption every 2-3 years of application.
\end{abstract}

Keywords: vineyard; early leaf removal; soil tillage; water potential; photosynthesis

\section{Introduction}

The Etna area (East Sicily, Southern Italy) is characterized by a wide variety of microclimate and soil composition; such environmental characteristics, coupled with adequate management practices, have a strong impact on grape and wine properties. The soil in which vineyards are planted is strongly influenced by the proximity to an active volcano and is basically sandy, well-drained, poor in fertility and subjected to water scarcity during the summer [1]. At present, for its sustainability and to ensure optimal must composition, grape production requires the application of both conservative soil practices and the use of effective canopy management strategies.

The increasing interest in the quality of wine production (e.g., terroirs) and the need of coupling wine-making with sustainable practices capable of maintaining or improving 
the soil fertility—mostly in the mountain areas [2]—are important aspects for the set-up of novel implants.

Generally, conventional soil management practices include three to four mechanical tillages per year for weed control or herbicide application. In addition, farmers usually increase the use of fertilizer to intensify vine growth and yield, with a corresponding enhancement of cost and pollution [3]. In contrast, conservative soil management practices such as zero or minimum tillage reduce erosion rates and moisture losses and increase organic matter content [4,5], with a positive effect on the yield and fruit quality traits [6]. Moreover, conservative soil management reduces the energetic costs $[7,8]$ related to field maintenance, and have beneficial effects on root growth, resulting in an improved soil volume explored by the plants $[9,10]$. Among the conservative practices (i.e., zero tillage, minimum tillage, mulch tillage and cover crops [11]), minimum tillage is a valid alternative to conventional tillage to control weed competition, vine vigor and bud fertility [6], avoiding the excessive water consumption observed with other techniques, such as the use of cover crops [12]. Compared to conventional tillage, the conservative soil strategies minimize the soil disturbance in terms of depth and till frequency, determining an increase in the storage of organic matter compared to conventionally tilled soils [13]. Generally, in conservative tillage systems (i.e., zero and minimum) the soil density in the untilled layers increases, but a greater biological density of the untilled layer may be counterbalanced by an increase in biological macroporosity and pore continuity [14].

Vine performance also depends on the agronomic practices related to the canopy control. Among these, leaf removal performed at an early stage of plant development (before bloom) represents an important tool for vine management, through a modification of the source-sink relationships [15-19]. In fact, a recent meta-analysis review reports that this management practice has an effect in the reduction of fruit yield and in the control of bunch rot disease. At the same time, leaf removal also has a positive effect on the accumulation of sugar, anthocyanins and polyphenols, mainly due to the increase in the leaf-to-fruit ratio [20]. Moreover, pre-bloom leaf removal could be of interest for vineyards in mountain areas and when late-ripening cultivars are used, especially determining a better canopy aeration and allowing a better control of fungal diseases. In this study we analyze the mid-term influence of minimum tillage combined with early leaf removal on the productive behavior and physiology on the autochthonous black grape cv. Nerello Mascalese.

\section{Materials and Methods}

\subsection{Site, Plant Material, Environment, and Experimental Design}

The research was carried out in a rainfed vineyard located on the Etna volcano (lat. $37^{\circ} 41^{\prime} 13^{\prime \prime} \mathrm{N}$; long. $15^{\circ} 07^{\prime} 00^{\prime \prime} \mathrm{E}$; elevation $602 \mathrm{~m}$ a.s.l., eastern-facing slope). Vines (Vitis vinifera L.) cv. Nerello Mascalese, grafted onto 140 Ru rootstock, were planted in 2010, in rows orientated ENE-WSW, spaced $2.5 \mathrm{~m}$ between rows and $1.2 \mathrm{~m}$ within rows. Vines were trained using a vertical-shoot positioned, spur-pruned permanent cordon at $0.7 \mathrm{~m}$ from the soil and the top of the canopy at approximately $1.80 \mathrm{~m}$. Vines were spur-pruned from six to eight nodes per vine (two nodes per spur and three to four spurs per vine).

Two soil management schemes and two canopy management treatments were arranged in a factorial combination to conduct the trial over four consecutive growing seasons, from 15 June 2015 to 30 January 2019. Here we present data from 2017 to 2018.

\subsection{Climate and Soil}

The climate of the trial site is reported in [18], where the monthly minimum, mean and maximum solar radiation; air temperature and rainfall in the experimental vineyard were registered (Figure 1). According to the USDA scheme [21], the soil is classified as loamy-sandy, as reported in a previous study performed on the same site [22]. 


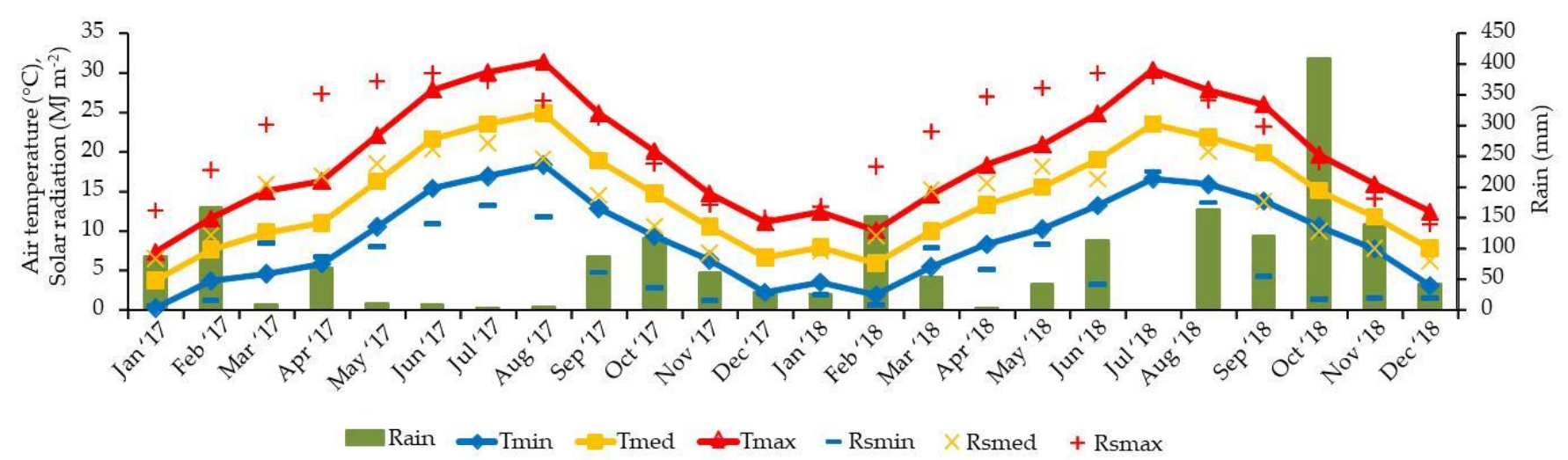

Figure 1. Monthly minimum (Rsmin), mean (Rsavg) and maximum (Rsmax) global radiation (MJ $\mathrm{m}^{-2}$ ); minimum (Tmin), mean (Tavg) and maximum (Tmax) air temperature $\left({ }^{\circ} \mathrm{C}\right)$ and total rainfall (mm) in the vineyard (lat. $37^{\circ} 41^{\prime} 13^{\prime \prime} \mathrm{N}$; long. $15^{\circ} 07^{\prime} 00^{\prime \prime}$ E; elevation $602 \mathrm{~m}$ a.s.l.) in 2017 and 2018.

\subsection{Vineyard Soil Management}

Two soil management schemes were compared: (i) minimum tillage (MT) and (ii) conventional tillage (CT). The MT treatment included just one mechanical tillage $(15 \mathrm{~cm}$ deep) in mid-April. Meanwhile, CT included three mechanical tillages per year, at the end of January (25 cm deep), in mid-April (15 cm deep) and in early July (10 cm deep).

\subsection{Vines Canopy Management}

Two canopy management practices were compared: (i) removal of all basal leaves on all shoots up to the leaf upper the last cluster (ELR: early leaf removal); (ii) no leaf removal (NLR). Each year, primary and lateral leaves were removed by hand at phenological growth stage BBCH61 (beginning of flowering: 10\% of flowerhoods fallen) [23]. At this stage, on five vines per treatment, the area of remaining and removed leaves from primary and lateral shoots and the length of primary and lateral shoots were measured. The area of removed leaves was determined using an area meter (model LI-3100; Licor, Inc., Lincoln, Nebraska). The total leaf area per vine, the removed leaf area per vine (independently from primary and lateral shoot) and their percentage incidence were calculated.

\subsection{Combined Treatments}

The four combined treatments analyzed were: (1) Early Leaf Removal-Minimum Tillage (ELR-MT), (2) No Leaf Removal-Minimum Tillage (NLR-MT), (3) Early Leaf RemovalConventional Tillage (ELR-CT), (4) No Leaf Removal-Conventional Tillage (NLR-CT).

\subsection{Experimental Design}

Three independent blocks were used, each consisting of 12 rows containing 60 vines each. The four combined treatments were applied on three rows inside each block. All measurements were made on five vines per treatment per block, selected in the central part of the rows.

\subsection{Physiological Measurements}

Midday stem water potential was measured by a Schöelander pressure chamber (Soil Moisture Equipment Corp., Sta. Barbara, CA, USA) according to [24]. Leaves were closed into a black hermetic plastic bag covered with an aluminum foil for at least $2 \mathrm{~h}$ before detachment from the vine and measurement. Net photosynthesis $(\mathrm{Pn})$ and transpiration (E) rates of well-exposed, fully expanded leaves from primary and lateral shoots were measured with a portable infrared gas analyzer LI-6400 (Li-Cor, Lincoln, NE, USA). All measurements were made each year from DOY 181 (30 June) to DOY 241 (29 August) every 
15 days from 12:00 p.m. to 1:30 p.m. For each treatment and date of measurement, data were collected from five fully exposed primary leaves and five lateral leaves.

\subsection{Vine Yield and Grape Composition}

In 2017 and 2018, yield per vine and grape composition were analyzed at harvest, which occurred on 15 and 29 September, respectively. Grapes were harvested when they reached optimal commercial maturity, according to the needs of the winery. Bunches were collected from 5 vines per treatment on each block to determine the yield assessment. A sample of five bunches per treatment on each block ( 15 bunches per treatment) was used to determine the bunch weight and the number and weight of berry. A 100-berry sample per experimental block was divided in three sub-samples, crushed with a manual press and free-run juice utilized to determine the total soluble solids (TSS) with a digital refractometer with temperature correction (RX-5000 Atago Co., Ltd., Bellevue, WA, USA), must $\mathrm{pH}$ and titratable acidity (TA), using an automatic titrator (Titrino model 798, Metrohm, Riverview, FL, USA) with $5.0 \mathrm{~mL}$ juice samples being titrated against $0.1 \mathrm{M} \mathrm{NaOH}$ to $\mathrm{pH}$ 8.2; TA was expressed as $\mathrm{g} / \mathrm{L}$ of tartaric acid equivalents. The total polyphenol content was determined using the Folin-Ciocalteu reagent assay $[25,26]$ and expressed as $\mathrm{mg} / \mathrm{kg}$ of grapes. Total anthocyanins were expressed as $\mathrm{mg} / \mathrm{kg}$ of fresh weight as reported by [27].

\subsection{Statistical Analysis}

Analysis of variance (ANOVA) was performed with Jamovi 1.2 statistical software [28]. One-way ANOVA was carried out on physiological and qualitative/productive traits to assess the effect of each treatment within each year, ANOVA was used to assess the differences among the soil and canopy treatments among the years and repeated measures ANOVA was performed to individuate differences between the two years of treatment at specific days of the year. A post-hoc analysis based on Tukey HSD test (Tukey honest significant differences) was performed at significance levels ( $p$-value) of $0.05,0.01$ and 0.001 .

\section{Results}

\subsection{Climate Variables}

The biannual average temperature was $14.2^{\circ} \mathrm{C}$ (Figure 1). During the study, the lowest minimum temperatures were recorded in January 2017 and February 2018. The warmest months in 2017 were July and August (daily mean temperature above $23^{\circ} \mathrm{C}$ ) and July in 2018. However, the degree days available were about 1545 GDD from bud burst to harvest in 2017 and 1563 GDD in 2018 (Figure 1). The growing degree days, calculated as $\sum$ Tmean -10 (value 10 is the base threshold temperature), were used to estimate the growth and development of vines during the growing season. Annual rainfall was about $650 \mathrm{~mm}$ in 2017 and $1250 \mathrm{~mm}$ in 2018. The driest month was July in both years (only $4.8 \mathrm{~mm}$ in 2017 and $0.6 \mathrm{~mm}$ in 2018); the rainfalls registered in August were $6.8 \mathrm{~mm}$ and $163.8 \mathrm{~mm}$ in 2017 and 2018 respectively, while rainfalls in September were $86.8 \mathrm{~mm}$ in 2017 and $120.8 \mathrm{~mm}$ in 2018. Even if after the harvest, it is interesting to note the extremely high amount of precipitation in October 2018, reaching $409.2 \mathrm{~mm}$.

\subsection{Leaf Removal Intensity}

In 2017 and 2018, an average of $8000 \mathrm{~cm}^{2}$ of leaves were removed from ELR vines corresponding to a canopy mean defoliation of about $44 \%$ in 2017 and 31\% in 2018 (Table 1). Moreover, in 2018 compared to 2017, a significant decrease in the leaf area removed from primary shoot was registered: 53\% in ELR-MT and 50\% in ELR-CT. 
Table 1. Impact of leaf removal on primary and lateral shoot leaf area and length in 2017 and 2018 seasons in the following combination: Early Leaf Removal-Minimum Tillage (ELR-MT) and Early Leaf Removal-Conventional Tillage (ELR-CT). Data are means \pm standard deviations. Means for each year indicated by different letters are significantly different $(p \leq 0.001)$ based on Tukey's HSD post hoc test within treatments.

\begin{tabular}{|c|c|c|c|c|}
\hline \multirow{2}{*}{ Parameters } & \multicolumn{2}{|c|}{2017} & \multicolumn{2}{|c|}{2018} \\
\hline & ELR-MT & ELR-CT & ELR-MT & ELR-CT \\
\hline Total leaf area/vine $\left(\mathrm{cm}^{2}\right)$ & $20,117 \pm 7.6$ & $24,798 \pm 4.0$ & $23,186 \pm 7.3$ & $16,398 \pm 7.2$ \\
\hline Removed total leaf area/vine $\left(\mathrm{cm}^{2}\right)$ & $9680 \pm 1.1$ & $10,276 \pm 1.0$ & $5959 \pm 2.5$ & $6168 \pm 3.4$ \\
\hline Removed total leaf area/vine (\%) & $48.1 \pm 5.5$ & $41.4 \pm 5.3$ & $25.7 \pm 6.9$ & $37.60 \pm 15.7$ \\
\hline Primary shoot length $(\mathrm{cm})$ & $122.4 \pm 6.9$ & $114.2 \pm 4.2$ & $138.0 \pm 31.1$ & $144.0 \pm 29.4$ \\
\hline Total leaf area/primary shoot $\left(\mathrm{cm}^{2}\right)$ & $2923 \pm 623$ & $2899 \pm 409$ & $2550 \pm 560$ & $1859 \pm 207$ \\
\hline Removed leaf area/primary shoot $\left(\mathrm{cm}^{2}\right)$ & $1182 \pm 166$ & $1033 \pm 129$ & $554.9 \pm 250$ & $512.3 \pm 239$ \\
\hline Lateral shoot length $(\mathrm{cm})$ & $24.6 \pm 4.9$ & $25.8 \pm 3.8$ & $14.30 \pm 4.8$ & $17.3 \pm 3.0$ \\
\hline Total leaf area/lateral shoot $\left(\mathrm{cm}^{2}\right)$ & $730.0 \pm 99$ & $777.6 \pm 101$ & $1314 \pm 710$ & $1265 \pm 524$ \\
\hline Removed leaf area/lateral shoot $\left(\mathrm{cm}^{2}\right)$ & $198.0 \pm 39.6 \mathrm{~B}$ & $300.2 \pm 52.9 \mathrm{~A}$ & $207.78 \pm 88.6$ & $194.14 \pm 73.0$ \\
\hline$p$-Level & \multicolumn{2}{|c|}{$190.0 \pm 39.0 \mathrm{D}_{* *} 300.2 \pm 32.9 \mathrm{~A}$} & \multicolumn{2}{|c|}{ n.s. } \\
\hline
\end{tabular}

For each year, interactions are indicated by: * Significant $p<0.05$; ** Significant $p<0.01$, based on Tukey's HSD test ( \pm standard deviation). n.s. = not significant.

\subsection{Physiological Measurements}

Concerning the stem water potential, in 2017 the ELR-MT treatment showed the best performance in both primary and lateral shoots, showing less-negative values at each date (Figure 2). However, similar results were reached by all the treatments at DOY 196 and 211 for the main shoots and at DOY 211 for the lateral shoots. NLR-MT showed the worst stem water potential values for both primary and lateral shoots at DOY 226 in 2017 and in primary shoots at DOY 211 in 2018, when the hottest temperatures were reached. CT also negatively affected the stem water potential (about $10 \%$ more negative than MT), but the ELR effect was positive, reducing vines' stress (i.e., the mean values in ELR vines were about $10 \%$ higher than in the NLR ones).

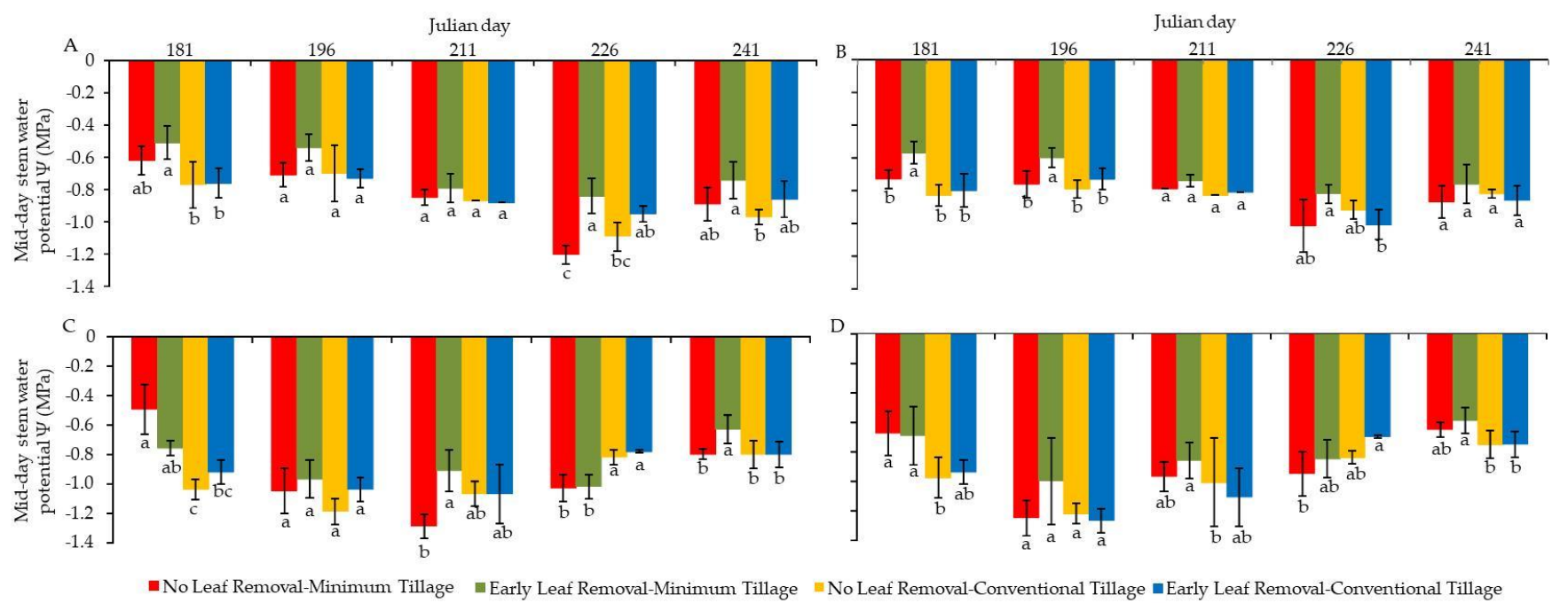

Figure 2. Mid-day stem water potential measured in 2017 ((A) primary leaves, (B) lateral leaves) and 2018 ((C) primary leaves, (D) lateral leaves) for the four combinations analyzed. For each year, treatment and day of the year, the values marked by different letters are significantly different $(p \leq 0.05)$ based on Tukey's HSD test (bars indicate \pm standard deviations).

The hottest months of 2017 were July and August, both characterized by a lack of rain (only $4.8 \mathrm{~mm}$ and $6.8 \mathrm{~mm}$, respectively) and higher air temperatures. In all treatments, the greatest vine stress, both in primary and lateral shoots, was detected at DOY 226 (Figure 2A,B; Supplementary Material, Tables S1 and S2). In 2018, the hottest and most 
arid month was July, with only $0.6 \mathrm{~mm}$ of rain, and the highest water stress was generally registered in the leaves of primary shoots on DOY 211 (stem water potential up to $-1.3 \mathrm{MPa}$ ) and in the leaves of lateral shoots mostly on DOY 196 (Supplementary Material, Tables S1 and S2). In August 2018, the rainfall reached $165 \mathrm{~mm}$ and the average air temperature was lower than 2017 (about $-1.53^{\circ} \mathrm{C}$ ) and the treatment ELR-MT confirmed the lowest values of water stress at DOY 211 and 241 both for primary and lateral shoots (Figure 2C,D). The effects of soil management and leaf removal in 2018 showed opposite results, and ELR confirmed its effectiveness in improving the stem water potential. Regardless of tillage, the NLR had the lowest stem water potential in mid-summer.

In 2017, the Pn rate in both primary and lateral leaves of ELR-MT vines was higher during July and August (Figure 3A,B), according to the optimal values of stem water potential (Figure 2). At DOY 226 and 241 the MT vines had significantly higher values of Pn compared to CT treatments, especially in the leaves of primary shoots, with values almost doubled (from 6 to $12 \mu$ mols $\mathrm{CO}_{2} \mathrm{~m}^{-2} \mathrm{~s}^{-1}$ ). In 2018, soil management determined fluctuating values of Pn in the leaves of both primary and lateral shoots; however, the positive effect of MT on Pn can be estimated as about 30\% (Figure 3C,D). In 2017, Pn and $\mathrm{E}$ rates in ELR-MT exhibited an opposite trend (Figures 3 and 4), suggesting that in this case the water availability was not a limiting factor for the assimilation process. On the contrary, for all the other treatments this statement cannot be not confirmed due to a strong variability in both physiological parameters. The year 2018 was characterized by a concentration of rain both in June $(115 \mathrm{~mm})$ and in August $(164 \mathrm{~mm})$, and this positively influenced the Pn at DOY 181 and 226 in MT treatments. While at DOY 226 the Pn values were similar to those of the previous year, at DOY 181 MT treatments (ELR-MT and NLRMT) increased their values (almost $+50 \%$ for both treatments). This could be due to a more efficient use of water resources, especially from young leaves, or to a higher water content into the soil.

The main effects of Year (Y), DOY (D), Canopy (C) and Tillage (T) on physiological parameters are reported in Table 2 . All the factors analyzed significantly influenced all the parameters, with the exception of $Y$, which did not affect transpiration rates on lateral shoots, and $\mathrm{T}$, which did not affect the transpiration rates of either primary or lateral shoots. Among the interactions between factors, the most significant were $\mathrm{Y} \times \mathrm{D}$ and $\mathrm{D} \times \mathrm{T}$, and as a direct consequence of these interactions, $\mathrm{Y} \times \mathrm{D} \times \mathrm{T}$ showed the same significance.
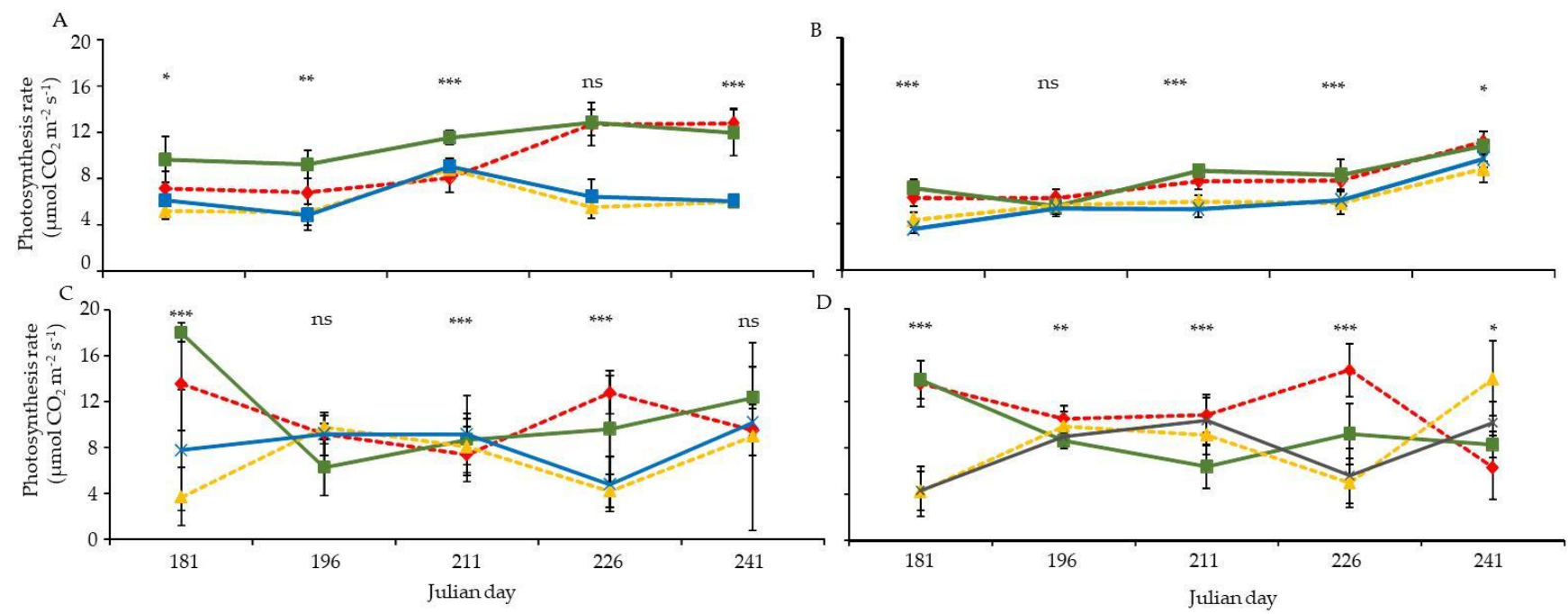

Figure 3. Net photosynthesis measured in 2017 ((A) primary leaves, (B) lateral leaves) and 2018 ((C) primary leaves, (D) lateral leaves) for the four combinations analyzed. For each year, ${ }^{*}{ }^{* *}$ and ${ }^{* * *}$ represent significant differences at $p<0.05$, 0.01 and 0.001, respectively, and ns indicates no significant difference, based on Tukey's HSD test ( \pm standard deviation). 

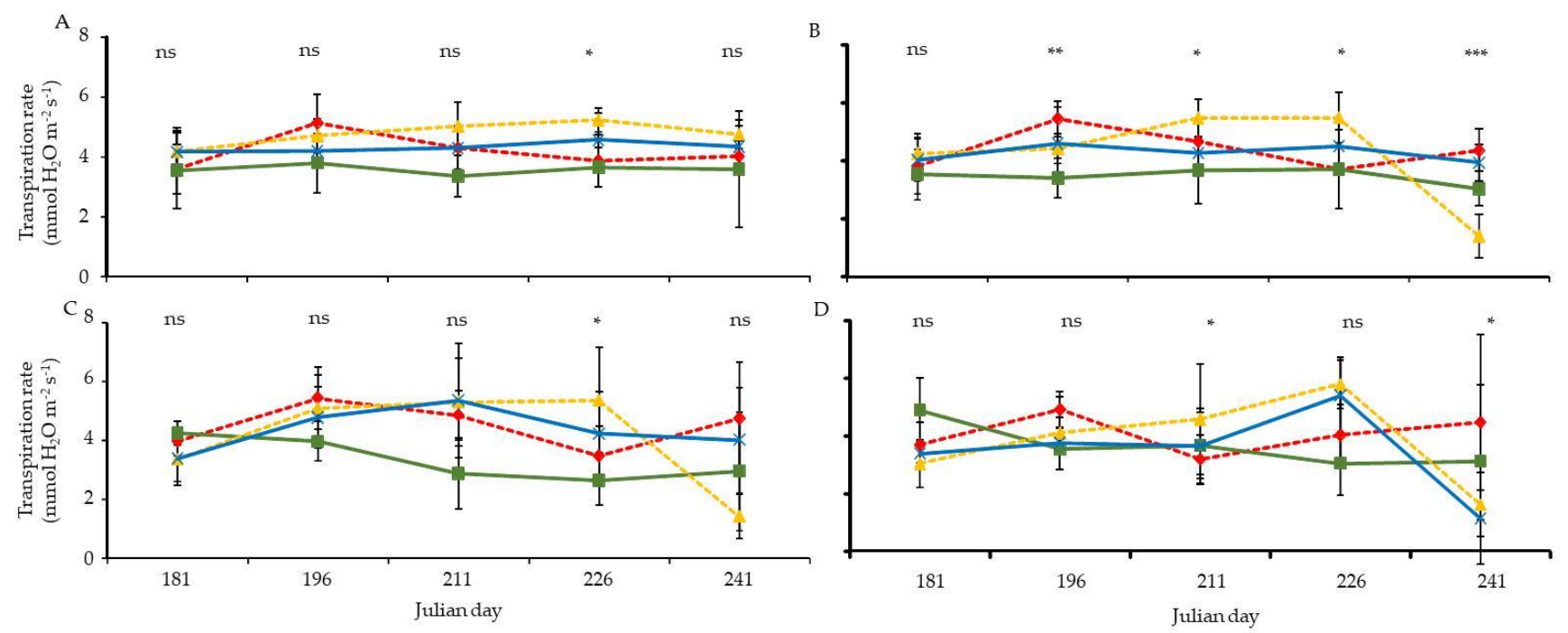

$\rightarrow-$ No Leaf Removal-Minimum Tillage $\rightarrow-$ Early Leaf Removal-Minimum Tillage $-\stackrel{-}{-}$-No Leaf Removal-Conventional Tillage $\rightarrow-$ Early Leaf Removal-Conventional Tillage

Figure 4. Transpiration rate measured in 2017 ((A) primary leaves, (B) lateral leaves) and 2018 ((C) primary leaves, (D) lateral leaves) for the four combinations analyzed. For each year, ${ }^{*},{ }^{* *}$ and ${ }^{* * *}$ represent significant differences at $p<0.05,0.01$ and 0.001 , respectively, and ns indicates no significant difference, based on Tukey's HSD test ( \pm standard deviation).

\subsection{Yield and Grape Composition at Harvest}

In 2017, no difference in yield per vine was found between treatments, nor for bunch and berry weight or number of berries per bunch (Table 3). In 2018, the yield per vine was significantly lower in ELR-MT ( $-24 \%$ in comparison to NLR-MT) and in ELR-CT ( $-38 \%$ in comparison to NLR-CT) due to reductions of both the bunch weight and the number of berries per bunch (Table 3). In 2017, the combination ELR-MT determined a higher TSS accumulation in the grapes $\left(+1.9^{\circ}\right.$ Brix $)$ compared to NLR-MT, and improved the content of anthocyanins $(+29 \%)$ and polyphenols $(+10 \%)$ (Table 3$)$. The anthocyanins/TSS ratio was also increased in the grapes from ELR-MT vines $\left(3.88 \mathrm{mg} \mathrm{kg}^{-1} /{ }^{\circ}\right.$ Brix versus an average of 3.36 found in the other three treatments). Moreover, the grape ripening in the ELR-MT treatment was earlier, as shown by AT values of $0.77 \mathrm{~g} / \mathrm{L}$ against an average of $0.95 \mathrm{~g} / \mathrm{L}$ found in the other three treatments.

In 2018, no significant differences were found in TSS, TA and must $\mathrm{pH}$ among treatments, whereas in the ELR-MT vines the total content of anthocyanins and polyphenols increased in comparison to NLR-MT ( $+44 \%$ and $+75 \%$, respectively) (Table 3 ). Similar to what was found in 2017, in 2018 the MT treatment also increased the anthocyanins/TSS ratio by about $35 \%$ in the grapes from ELR vines and by $46 \%$ in NLR vines.

As shown in Table 4, among the factors evaluated in the trial (Year (Y), Canopy (C) and Tillage $(\mathrm{T})$ ), the weather trends of the years ( $\mathrm{Y}$ factor) influenced most of the parameters, except for TA, total polyphenols and total anthocyanins/TSS ratio. On the contrary, none of the interactions between factors revealed any significance concerning the pomological parameters, while among the qualitative parameters only TSS $(\mathrm{Y} \times \mathrm{T}$ and $\mathrm{C} \times \mathrm{T})$ and TA $(\mathrm{Y} \times \mathrm{C}$ and $\mathrm{Y} \times \mathrm{T})$ registered a significant effect. 
Table 2. Tukey's post-hoc test ANOVA on yield characteristics and main berry quality attributes. Interactions are indicated by: ${ }^{*}$ Significant $p<0.05 ; * *$ Significant $p<0.01 ; * *$ Significant $p<0.001$.

\begin{tabular}{|c|c|c|c|c|c|c|c|c|c|c|c|c|c|c|c|}
\hline Parameters & $\begin{array}{l}\text { Year } \\
\text { (Y) }\end{array}$ & $\begin{array}{l}\text { Day of the } \\
\text { Year (D) }\end{array}$ & $\begin{array}{l}\text { Canopy } \\
\text { (C) }\end{array}$ & $\begin{array}{l}\text { Tillage } \\
\text { (T) }\end{array}$ & $\mathbf{Y} \times \mathbf{D}$ & $\mathrm{Y} \times \mathrm{C}$ & $\mathbf{D} \times \mathbf{C}$ & $\mathbf{Y} \times \mathbf{T}$ & $\mathbf{D} \times \mathbf{T}$ & $\mathrm{C} \times \mathrm{T}$ & $\mathbf{Y} \times \mathbf{D} \times \mathbf{C}$ & $\mathbf{Y} \times \mathbf{D} \times \mathbf{T}$ & $\mathbf{Y} \times \mathbf{C} \times \mathbf{T}$ & $\mathbf{D} \times \mathbf{C} \times \mathbf{T}$ & $\mathbf{Y} \times \mathbf{D} \times \mathbf{C} \times \mathbf{T}$ \\
\hline $\begin{array}{c}\text { Mid-day stem water } \\
\text { potential (MPa) } \\
\text { Primary leaves }\end{array}$ & $* * *$ & $* * *$ & $* * *$ & $* * *$ & $* * *$ & ns & ns & ns & $* * *$ & ns & * & ** & ns & * & $* *$ \\
\hline $\begin{array}{l}\text { Mid-day stem water } \\
\text { potential (MPa) } \\
\text { Lateral leaves }\end{array}$ & $* * *$ & $* * *$ & $* * *$ & $* * *$ & $* * *$ & ns & ns & ns & $* * *$ & $* *$ & ns & $* * *$ & ns & ns & ns \\
\hline $\begin{array}{c}\text { Net photosynthesis } \\
\left(\mu \mathrm{mol} \mathrm{CO} \mathrm{C}_{2}^{-2} \mathrm{~s}^{-1}\right) \\
\text { Primary leaves }\end{array}$ & ** & $* *$ & $* *$ & $* * *$ & *** & ns & * & ns & $* * *$ & ns & $*$ & $* * *$ & ns & ns & ns \\
\hline $\begin{array}{c}\text { Net photosynthesis } \\
\left(\mu \mathrm{mol} \mathrm{CO} \mathrm{m}^{-2} \mathrm{~s}^{-1}\right) \\
\text { Lateral leaves }\end{array}$ & $* * *$ & $* * *$ & $* *$ & $* * *$ & $* * *$ & $* *$ & ns & ns & $* * *$ & ns & ns & $* * *$ & * & $* * *$ & $* * *$ \\
\hline $\begin{array}{c}\text { Transpiration rate } \\
\left(\text { mmol } \mathrm{H}_{2} \mathrm{O} \mathrm{m}^{-2} \mathrm{~s}^{-1}\right) \\
\text { Primary leaves }\end{array}$ & $* *$ & $* * *$ & $* *$ & ns & * & ns & ns & * & $* * *$ & ns & ns & $* * *$ & ns & ns & ns \\
\hline $\begin{array}{c}\text { Transpiration rate } \\
\left(\text { mmol H}_{2} \mathrm{O} \mathrm{m}^{-2} \mathrm{~s}^{-1}\right) \\
\text { Lateral leaves }\end{array}$ & ns & $* * *$ & $* *$ & ns & ns & ns & $* *$ & ns & $* * *$ & $* * *$ & ns & ns & ns & $* * *$ & ns \\
\hline
\end{tabular}

Table 3. Impact of early basal leaf removal and soil tillage on yield components and main berry quality attributes (NLR-CT = No Leaf Removal-Conventional Tillage; NLR-MT = No Leaf Removal-Minimum Tillage; ELR-CT = Early Leaf Removal-Conventional Tillage; ELR-MT = Early Leaf Removal-Minimum Tillage). Data are presented as means \pm standard deviations. Means for each parameter indicated by different letters are significantly different $(p \leq 0.05)$, based on Tukey's HSD post hoc test within treatment and year.

\begin{tabular}{|c|c|c|c|c|c|c|c|c|}
\hline \multirow{2}{*}{ Parameters } & \multicolumn{4}{|c|}{2017} & \multicolumn{4}{|c|}{2018} \\
\hline & NLR-CT & NLR-MT & ELR-CT & ELR-MT & NLR-CT & NLR-MT & ELR-CT & ELR-MT \\
\hline Yield/vine (kg) & $1.43 \pm 0.96 \mathrm{a}$ & $1.71 \pm 0.55 \mathrm{a}$ & $1.60 \pm 0.54 \mathrm{a}$ & $1.70 \pm 0.70 \mathrm{a}$ & $0.98 \pm 0.05 \mathrm{~A}$ & $0.83 \pm 0.12 \mathrm{~A}$ & $0.60 \pm 0.09 \mathrm{~B}$ & $0.63 \pm 0.08 \mathrm{~B}$ \\
\hline Bunch/vine $\left(\mathrm{n}^{\circ}\right)$ & $4 \pm 3.23 \mathrm{a}$ & $4.72 \pm 2.23 \mathrm{a}$ & $4.96 \pm 1.91 \mathrm{a}$ & $5.61 \pm 3.64 \mathrm{a}$ & $3.1 \pm 0.31 \mathrm{a}$ & $3.06 \pm 0.8 \mathrm{a}$ & $3.47 \pm 1.25 \mathrm{a}$ & $3.9 \pm 0.43 \mathrm{a}$ \\
\hline Bunch weight $(\mathrm{g})$ & $398.0 \pm 111 \mathrm{a}$ & $383.3 \pm 106 \mathrm{a}$ & $328.6 \pm 74 \mathrm{a}$ & $340.0 \pm 87 a$ & $316.5 \pm 19 \mathrm{a}$ & $285.0 \pm 87 a$ & $182.6 \pm 35 b$ & $163.9 \pm 26 b$ \\
\hline Berry weight (g) & $2.76 \pm 0.04 \mathrm{a}$ & $2.89 \pm 0.11 \mathrm{a}$ & $2.17 \pm 0.13 \mathrm{a}$ & $2.81 \pm 0.04 \mathrm{a}$ & $2.14 \pm 0.30 \mathrm{a}$ & $2.52 \pm 0.51 \mathrm{a}$ & $2.16 \pm 0.50 \mathrm{a}$ & $2.50 \pm 0.50 \mathrm{a}$ \\
\hline Berries/bunch (n.) & $144.4 \pm 42.9 \mathrm{a}$ & $133.4 \pm 40.8 \mathrm{ab}$ & $119.6 \pm 28.4 \mathrm{~b}$ & $121.0 \pm 31.7 \mathrm{ab}$ & $149.7 \pm 19.2 \mathrm{a}$ & $119.9 \pm 52.1 \mathrm{ab}$ & $90.8 \pm 39.4 \mathrm{ab}$ & $68.0 \pm 17.5 \mathrm{~b}$ \\
\hline Total soluble solids ( ${ }^{\circ}$ Brix) & $19.94 \pm 0.38 \mathrm{~B}$ & $20.37 \pm 0.72 \mathrm{~B}$ & $20.14 \pm 0.87 \mathrm{~B}$ & $21.95 \pm 0.40 \mathrm{~A}$ & $20.450 .86 \mathrm{ab}$ & $19.32 \pm 1.09 \mathrm{~b}$ & $19.64 \pm 0.69 \mathrm{~b}$ & $20.88 \pm 0.49 a$ \\
\hline Titratable acidity (g/L) & $10.0 \pm 0.8 \mathrm{~A}$ & $9.0 \pm 0.3 \mathrm{~A}$ & $9.4 \pm 0.7 \mathrm{~A}$ & $7.7 \pm 0.1 \mathrm{~B}$ & $8.2 \pm 0.5 b$ & $9.0 \pm 0.9 \mathrm{ab}$ & $8.4 \pm 0.4 \mathrm{~b}$ & $9.5 \pm 0.3 \mathrm{a}$ \\
\hline Must pH & $3.17 \pm 0.04 \mathrm{ab}$ & $3.26 \pm 0.09 a$ & $3.17 \pm 0.04 \mathrm{ab}$ & $3.14 \pm 0.02 b$ & $3.37 \pm 0.04 \mathrm{ab}$ & $3.33 \pm 0.08 \mathrm{a}$ & $3.29 \pm 0.06 \mathrm{ab}$ & $3.27 \pm 0.10 \mathrm{~b}$ \\
\hline Total anthocyanins $(\mathrm{mg} / \mathrm{kg} \mathrm{fw})$ & $61.33 \pm 33 a$ & $76.29 \pm 16 \mathrm{a}$ & $66.05 \pm 22 \mathrm{a}$ & $85.41 \pm 29 \mathrm{a}$ & $56.45 \pm 20 \mathrm{a}$ & $77.50 \pm 19 \mathrm{a}$ & $51.55 \pm 11 \mathrm{a}$ & $74.25 \pm 13 \mathrm{a}$ \\
\hline Total polyphenols ( $\mathrm{mg} / \mathrm{kg} \mathrm{fw}$ ) & $1198 \pm 251 \mathrm{a}$ & $1081.2 \pm 119 \mathrm{a}$ & $1130.4 \pm 78 \mathrm{a}$ & $1246.8 \pm 62 \mathrm{a}$ & $527.35 \pm 240 \mathrm{a}$ & $570.82 \pm 222 \mathrm{a}$ & $431.92 \pm 115 \mathrm{a}$ & $755.16 \pm 123 a$ \\
\hline Total anthocyanins $/{ }^{\circ} \mathrm{TSS}$ ratio & $3.08 \pm 1.7 \mathrm{a}$ & $3.73 \pm 0.71 \mathrm{a}$ & $3.27 \pm 1.07 \mathrm{a}$ & $3.89 \pm 1.34 \mathrm{a}$ & $2.76 \pm 0.97 \mathrm{a}$ & $4.04 \pm 1.12 \mathrm{a}$ & $2.63 \pm 0.61 \mathrm{a}$ & $3.56 \pm 0.67 \mathrm{a}$ \\
\hline
\end{tabular}


Table 4. Tukey's post-hoc test ANOVA on yield characteristics and main berry quality attributes. Interactions are indicated by: * Significant $p<0.05 ;{ }^{* *}$ Significant $p<0.01 ; * * *$ Significant $p<0.001$.

\begin{tabular}{|c|c|c|c|c|c|c|c|}
\hline Parameters & Year (Y) & Canopy (C) & Tillage (T) & $\mathbf{Y} \times \mathbf{C}$ & $\mathbf{Y} \times \mathbf{T}$ & $\mathbf{C} \times \mathbf{T}$ & $\mathbf{Y} \times \mathbf{C} \times \mathbf{T}$ \\
\hline Yield/vine (kg) & $* * *$ & ns & ns & ns & ns & ns & ns \\
\hline Bunch/vine $\left(\mathrm{n}^{\circ}\right)$ & * & ns & ns & ns & ns & ns & ns \\
\hline Bunch weight (g) & $* * *$ & $* * *$ & ns & ns & ns & ns & ns \\
\hline Berry weight (g) & $* * *$ & ns & * & ns & ns & ns & ns \\
\hline Berry/bunch (n.) & ** & ns & ns & ns & ns & ns & ns \\
\hline Total soluble solids ( ${ }^{\circ}$ Brix) & * & $* *$ & * & ns & * & $* * *$ & ns \\
\hline Titratable acidity (g/L) & ns & ns & ns & $* * *$ & *** & ns & ns \\
\hline Must pH & $* * *$ & $* *$ & ns & ns & ns & ns & ns \\
\hline Total anthocyanins (mg/kg fw) & $* * *$ & ns & ns & ns & ns & ns & ns \\
\hline Total polyphenols (mg/kg fw) & ns & ns & $* *$ & ns & ns & ns & ns \\
\hline Total anthocyanins/TTS ratio & ns & ns & * & ns & ns & ns & ns \\
\hline
\end{tabular}

\section{Discussion}

Nerello Mascalese is one of the traditional grape varieties in the Etna area, and in recent decades it registered an increased interest due to its use for wine making. This variety is characterized by high acidity and low anthocyanins accumulation; moreover, the acylated derivatives are very scarce (lower than $1 \%$ of the total). Therefore, the resulting wine can be poor of color and sometimes difficult to age [29]. These defects increase in years characterized by either frequent rains and cool summers, or by excessive drought. In these situations, canopy and soil management techniques regulating the microclimate of fruit zone and vine physiology may improve the evolution of grape ripening. This study was conducted in an area that is often characterized by a rainy period starting from October until March, and a dry period from the last days of the spring until the end of summer, in which rains may occur in the last phases of grape ripening, increasing the incidence and severity of rots. Soils are extremely sandy, deep and often with a high skeleton content [6]. Vineyards are not irrigated, and therefore water stress may be frequent due to the low soil water retention and the paucity of mid-summer precipitation. In the studied area, soil management is still commonly carried out by mechanical tillage (three/four times per year with a need of more than $100 \mathrm{~h}$ of labor per hectare), while canopy defoliation is performed in the last stages of bunch ripening in order to improve light interception and grape composition and prevent fungal diseases. Many studies in recent years have focused on the effects of early defoliation and canopy management on the yield and quality aspects of grapes [30-33], and on the benefits of conservative tillage in order to reduce organic matter loss and erosion rates and increase moisture retention in the soils $[2,4,34]$. In previous research, we analyzed-in different climate areas and both in rainfed and irrigated vineyards - the influence of early leaf removal, identifying benefits in terms of yield traits and disease control [17-27]. Koblet et al. [35] reported a yield decrease as a consequence of vine defoliation due to a decrease in cluster weight following a reduction in berry weight. The registered differences concerning the TSS in the ELR-MT treatment were due to a higher and extended sunlight exposure of the grapes. This condition might positively impact cellular growth in the berry, counteracting carbohydrate limitations [33]. Regarding soil management, is important to highlight that the vineyard is located in an area which has a highly seasonal rainfall pattern and a dry period which corresponds with the phenological stages of late flowering, berry set, veràison and ripening. Here the soil and atmospheric water deficits, in combination with high air temperatures, exert complex effects on fruit yield and berry composition [36]. In the study area, these conditions are particularly limiting because of the soil's physical characteristics, and because of its low content of organic matter-especially on the east-facing slopes. The yield reduction in 2018 probably depended not only on the LR treatment but also the MT treatment. Our 
results agree with Lopes et al. [37], who reported an increase of competition between vines and weeds (cover crops) for water that resulted in significant yield reductions. On the contrary, Monteiro and Lopes [12] reported that conservation tillage did not affect yield. We aimed to understand how the combination of both soil and canopy management practices could affect vine physiology, yield and grape composition. In our study, after three consecutive seasons of application, the ELR technique (irrespective of soil tillage) lowered bunch weight as a consequence of fruit-set reduction and therefore a lower number of berries per bunch, and was responsible for the significant yield reduction in 2018. On the other hand, Lebon et al. [38] reported that carbohydrates depression due to leaf removal before flowering exerts a negative impact on sugar flow, the meiosis process in flowers and finally in the bud fertility. This behavior could be responsible for an increase of the vegetative/reproductive balance, notwithstanding the increase not in the number of leaves or their total area, but in shoot length in CT treatments. In fact, in these treatments, the percentage of the removed leaf area was lower in 2018 than in 2017. This difference resulted from a restriction of the area of interest to the defoliation in the whole canopy, meaning that the fruiting shoots of the CT vines reduced the distal bud fertility. This behavior was probably due to an increase of the vegetative activity of the CT vines over the years, causing a modification of the reproductive and vegetative balance. However, this effect could be exploited for highly vigorous cultivars characterized by big and compact bunches to reduce yield and obtain looser bunches. This could also be considered as a tool in the controlled 'designation of origin' areas to maintain the yield per hectare within the imposed limits. However, for the low-vigor cultivars and for the conditions of this trial, the yield reduction obtained must be considered as a negative result. However, next to the diminished yield found in 2018, in general the ELR treatment exerted a positive effect on TSS accumulation, and in 2017 also caused a fast reduction of TA, showing an earlier grape ripening. In ELR treatment, the soil management did not modify yield and grape composition in 2017, whereas in 2018 when matched with MT treatment the TSS, anthocyanins and polyphenols content significantly increased in comparison to CT. This coupled treatment could be taken into account, but it is important to consider that the abovementioned results, found in 2018, were probably also due to the drastic reduction in yield per vine recorded in that year. The analysis of the factors Year (Y), Canopy (C) and Tillage (T) in interaction showed that the most influencing factor on the pomological parameters was the Y. However, this factor alone was not able to significantly influence some of the qualitative parameters (TA, Total polyphenols, Total anthocyanins/TSS). Canopy and tillage management were efficient for the modification of the TSS and TA. These parameters are those mainly considered by winegrowers for cellar operations. Therefore, the validity and economic convenience of the coupled treatment ELR-MT for consecutive years is cultivar- and site-dependent. Interestingly, in both years and irrespective of leaf removal, the MT increased the anthocyanins/TSS ratio compared to CT by about $20 \%$ in 2017 and $40 \%$ in 2018 , on average. Therefore, considering the reduction of about $60-70 \%$ of the labor needs for soil management, MT treatment could be a valid strategy in comparison to CT, especially when matched with ELR.

Each factor analyzed (Y, D, C and T) showed a strong influence on almost all the physiological parameters considered. Among the interactions, $\mathrm{Y} \times \mathrm{D}$ and $\mathrm{D} \times \mathrm{T}$ showed the strongest impact on all the parameters, meaning that the two years had a totally different impact on the vines thanks to the different meteorological trends during the two summer seasons. In any case, for each season, $\mathrm{T}$ treatment was a strong influencing factor for vines' physiological responses. The interaction $C \times T$ was less impactful on the vines' performances, and for the two years considered $(\mathrm{Y} \times \mathrm{C})$. As expected, when NLR was paired with MT treatment, the values of stem water potential increased (up to $-1.3 \mathrm{MPa}$ ). This fact highlights that MT plays a positive role in water retention in the upper layers of soil in which roots may grow undisturbed [39], but the development of more weeds and higher total leaf area per vine can determine a higher water requirement. 
Despite the fact that $445 \mathrm{~mm}$ of rain were registered from April to September in 2018 (+285 mm compared to 2017), a reduction in both leaf area and yield per vine was observed in comparison to 2017, with the exception for total leaf area in the ELR-MT treatment. These behaviors are probably related to a decrement of the replenishment of reserves in storage organs during the previous three years of ELR application (i.e., from 2015 to 2017), leading to a negative effect on bud fertility. For these reasons, the combined treatment ELR-MT requires an interruption every 2-3 consecutive years of application.

\section{Conclusions}

The proposed integrated agronomic practices concerning the soil (minimum tillage vs. conventional tillage) and the canopy (early leaf removal vs. no leaf removal) management may represent a valid tool to improve grape composition and maintain good yield. In the combined ELR-MT strategy, yield per vine was not compromised during the consecutive 2-3 years of application, whereas in 2018 (fourth year of application) it was strongly penalized, probably due to excessive depletion of nutritional reserves, reducing bud fertility, as well as unfavorable climate conditions. For all these reasons, the combination treatment ELR-MT must be interrupted every 2-3 years of application. Moreover, the combination ELR-MT in the autochthonous Nerello Mascalese black cultivar gave the most efficient outcome at a physiological level, maintaining a better water status and photosynthetic activity, ensuring a higher concentration of sugars and total anthocyanins and polyphenols in the grapes, in addition to saving the labor needed for conventional management.

Supplementary Materials: The following are available online at https: / www.mdpi.com/article/ 10.3390/agronomy11061070/s1. Table S1: $p$-Values of the post hoc Tukey's HSD test on repeated measure ANOVA for each dependent variable per DOY $(181,196,211,226,241)$ per year $(2017$ vs. 2018). Table S2: $p$-Values of post hoc Tukey's HSD test on repeated measure ANOVA for each dependent variable per treatment (ELR/NLR; MT/CT) per year (2017 vs. 2018).

Author Contributions: Conceptualization, E.N. and F.F.; methodology, E.N., F.F. and G.L.C.; validation, E.N., F.F., A.G., G.D., M.D.G., S.L.M. and A.P.; investigation, E.N., F.F., V.I. and G.L.C.; data curation, F.F. and V.I.; writing-original draft preparation, F.F., E.N. and V.I.; writing-review and editing, E.N., F.F., G.D., M.D.G., V.I. and A.P.; supervision, A.P., A.G. and S.L.M. All authors have read and agreed to the published version of the manuscript.

Funding: This research received no external funding.

Conflicts of Interest: The authors declare no conflict of interest.

\section{References}

1. Cicala, A.; Continella, A.; Ferlito, F. Preliminary results of primocane-fruiting red raspberry cultivars in Sicily. Acta Hortic. 2002, 585, 191-198. [CrossRef]

2. Varga, P.; Májer, J.; Jahnke, G.G.; Németh, C.; Szőke, B.; Sárdi, K.; Varga, Z.; Kocsis, L.; Salamon, B. Adaptive nutrient supply and soil cultivation methods in the upper zone of Hillside vineyards. Soil Sci. Plant Anal. 2012, 43, 334-340. [CrossRef]

3. Tegtmeier, E.M.; Duffy, M.D. External costs of agricultural production in the United States. Int. J. Agric. Sust. 2002, 2, 1-20. [CrossRef]

4. Ingels, C.A.; Scow, K.M.; Whisson, D.A.; Drenovsky, R.E. Effects of cover crops on grapevines, yield, juice composition, soil microbial ecology, and gopher activity. Am. J. Enol. Vitic. 2005, 56, 19-29.

5. Ciaccia, C.; La Torre, A.; Ferlito, F.; Testani, E.; Battaglia, V.; Salvati, L.; Roccuzzo, G. Agroecological practices and agrobiodiversity: A case study on organic orange in southern Italy. Agronomy 2019, 9, 85. [CrossRef]

6. Nicolosi, E.; Ferlito, F.; Allegra, M.; Cicala, A.; Trovato, F.; La Malfa, S. Influences of aspect and tillage on two winegrape cultivars on Mount Etna. N. Z. J. Crop Hortic. Sci. 2016, 44, 83-102. [CrossRef]

7. Horwath, W.R.; Mitchell, J.P.; Six, J.W. Tillage and Crop Management Effects on Air, Water, and Soil Quality in California; University of California Division of Agriculture and Natural Resource: Davis, CA, USA, 2008; pp. 1-9.

8. McLaughlin, A.; Mineau, P. The impact of agricultural practices on biodiversity. Agric. Ecosyst. Environ. 1995, 55, $201-212$. [CrossRef]

9. Howell, C.L.; Lanyon, D.M.; McCarthy, M. Effect of Vineyard Traffic and Soil Management Practices on Berry Growth, Grape Juice Parameters and Yield of Shiraz in the Barossa Valley. In Proceedings of the 13th Australian Wine Industry Technical Conference, Adelaide, Australia, 28 July-2 August 2007. 
10. Ferlito, F.; Distefano, G.; Gentile, A.; Allegra, M.; Lakso, A.N.; Nicolosi, E. Scion-rootstock interactions influence the growth and behaviour of the grapevine root system in a heavy clay soil. Aust. J. Grape Wine Res. 2020, 26, 68-78. [CrossRef]

11. Gebhardt, M.R.; Daniel, T.C.; Schweizer, E.E.; Allmaras, R.R. Conservation tillage. Science 1985, 230, 625-630. [CrossRef] [PubMed]

12. Monteiro, A.; Lopes, C.M. Influence of cover crop on water use and performance of vineyard in Mediterranean Portugal. Agric. Ecosyst. Environ. 2007, 121, 336-342. [CrossRef]

13. Jacobs, A.; Rauber, R.; Ludwig, B. Impact of reduced tillage on carbon and nitrogen storage of two Haplic Luvisols after 40 years. Soil Tillage Res. 2009, 102, 158-164. [CrossRef]

14. Rasmussen, K.J. Impact of ploughless soil tillage on yield and soil quality: A Scandinavian review. Soil Tillage Res. 1999, 53, 3-14. [CrossRef]

15. Palliotti, A.; Poni, S.; Gatti, M. Early-leaf removal to improve vineyard efficiency: Gas exchange, source-to-sink balance and reserve storage responses. Am. J. Enol. Viticul. 2011, 62, 219-228. [CrossRef]

16. Palliotti, A.; Gardi, T.; Berrios, J.G.; Civardi, S.; Poni, S. Early source limitation as a tool for yield control and wine quality improvement in a high-yielding red Vitis vinifera L. cultivar. Sci. Hortic. 2012, 145, 10-16. [CrossRef]

17. Nicolosi, E.; Continella, A.; Gentile, A.; Cicala, A.; Ferlito, F. Influence of early leaf removal on autochthonous and international grapevines in Sicily. Sci. Hortic. 2012, 146, 1-6. [CrossRef]

18. Lo Cicero, L.; Puglisi, I.; Nicolosi, E.; Gentile, A.; Ferlito, F.; Continella, A.; Lo Piero, A.R. Anthocyanin levels and expression analysis of biosynthesis-related genes during ripening of Sicilian and international grape berries subjected to leaf removal and water deficit. J. Agric. Sci. Technol. 2016, 18, 1333-1344.

19. Ferlito, F.; Allegra, M.; Torrisi, B.; Pappalardo, H.; Gentile, A.; La Malfa, S.; Continella, A.; Stagno, F.; Nicolosi, E. Early defoliation effect on water status, fruit yield and must quality of 'Nerello mascalese' grapes. Sci. Agric. 2020, 77, 1-10. [CrossRef]

20. Weide, J.V.; Gottschalk, C.; Schultze, S.R.; Nasrollahiazar, E.; Poni, S.; Sabbatini, P. Impacts of pre-bloom leaf removal on wine grape production and quality parameters: A systematic review and meta-analysis. Front. Plant. Sci. 2021, 11, 621585.

21. Klingebiel, A.A.; Montgomery, P.H. Land Capability Classification; Handbook 210; Agriculture USDA: Washington, DC, USA, 1961.

22. Agnelli, A.E.; Corti, G.; Agnelli, A.; Carlo, P.D.; Coltelli, M.; Ugolini, F.C. Features of some paleosols on the flanks of Etna volcano (Italy) and their origin. Geoderma 2007, 142, 112-126. [CrossRef]

23. Lorenz, D.H.; Eichorn, H.; Bleiholder, H.; Klose, R.; Meier, U.; Weber, E. Phänologische entwicklungsstadien der weinrebe (Vitis vinifera (L.) ssp. vinifera) codierung und beschreiibung nach der erweiterten BBCH-skala. Vitic. Enol. Sci. 1994, 49, 66-70.

24. Puglisi, I.; Nicolosi, E.; Vanella, D.; Lo Piero, A.R.; Stagno, F.; Saitta, D.; Roccuzzo, G.; Consoli, S.; Baglieri, A. Physiological and Biochemical Responses of Orange Trees to Different Deficit Irrigation Regimes. Plants 2019, 8, 423. [CrossRef]

25. Singleton, V.L.; Orthofer, R.; Lamuela-Raventós, R.M. Analysis of total phenols and other oxidation substrates and antioxidants by means of Folin-Ciocalteau reagent. Methods Enzymol. 1999, 299, 152-178. [CrossRef]

26. Nicolosi, E.; Ferlito, F.; Amenta, M.; Rapisarda, P. Changes in the quality and antioxidant components of minimally processed table grapes during storage. Sci. Hortic. 2018, 232, 175-183. [CrossRef]

27. Ferlito, F.; Nicolosi, E.; Gentile, A.; Lo Piero, A.R.; Squadrito, M.; Continella, A. Response of four grapevines to water stress and canopy management in an arid environment. Vitis 2014, 53, 73-80.

28. The Jamovi Project. Jamovi. (Version 1.2) [Computer Software]. 2020. Available online: https:/ /www.jamovi.org (accessed on 8 November 2020).

29. Squadrito, M.; Corona, O.; Ansaldi, G.; Di Stefano, R. Evolution of anthocyanin profile from grape to wine. J. Int. Sci. Vigne Vin. 2010, 44, 167-177. [CrossRef]

30. Diago, M.P.; Ayestarán, B.; Guadalupe, Z.; Garrido, Á.; Tardaguila, J. Phenolic composition of Tempranillo wines following early defoliation of the vines. J. Sci. Food Agric. 2012, 92, 925-934. [CrossRef]

31. Intrieri, C.; Filippetti, I.; Allegro, G.; Centinari, M.; Poni, S. Early defoliation (hand vs. mechanical) for improved crop control and grape composition in Sangiovese (Vitis vinifera L.). Aust. J. Grape Wine Res. 2008, 14, 25-32. [CrossRef]

32. Poni, S.; Bernizzoni, F.; Civardi, S. The effect of early leaf removal on whole-canopy gas exchange and vine performance of Vitis vinifera L. 'Sangiovese'. Vitis 2008, 47, 1.

33. Hunter, J.J.; Villiers, O.T.D.; Watts, J.E. The effect of partial defoliation on quality characteristics of Vitis vinifera L. cv. Cabernet Sauvignon grapes 1. Sugars, acids and pH. S. Afr. J. Enol. Vitic. 1991, 12, 42-50. [CrossRef]

34. Novara, A.; Gristina, L.; Saladino, S.S.; Santoro, A.; Cerdà, A. Soil erosion assessment on tillage and alternative soil managements in a Sicilian vineyard. Soil Tillage Res. 2011, 117, 140-147. [CrossRef]

35. Koblet, W.; Candolfi-Vasconcelos, M.C.; Zweifel, W.; Howell, S. Influence of leaf removal, rootstock, and training system on yield and fruit composition of Pinot noir grapevines. Am. J. Enol. Vitic. 1994, 61, 181-187.

36. Chaves, M.M.; Santos, T.P.; Souza, C.R.; Ortuno, M.F.; Rodrigues, C.M.; Lopes, M.L.; Maroco, J.P.; Pereira, J.S. Deficit irrigation in grapevine improves water-use efficiency while controlling vigour and production quality. Ann. Appl. Biol. 2007, 150, 237-252. [CrossRef]

37. Lopes, C.M.; Monteiro, A.; Machado, J.P.; Fernandes, N.; Araujo, A. Cover cropping in a sloping, non-irrigated vineyard: II-effects on vegetative growth, yield, berry and wine quality of 'Cabernet Sauvignon' grapevines. Cienc. Tec. Vitiv. 2008, 23, 37-43. 
38. Lebon, G.; Duchene, E.; Brun, O.; Magne, C.; Clement, C. Flower abscission and inflorescence carbohydrates in sensitive and non-sensitive cultivars of grapevine. Sex. Plant Reprod. 2004, 17, 71-79. [CrossRef]

39. Hill, R.L.; Horton, R.; Cruse, R.M. Tillage effects on soil water retention and pore size distribution of two mollisols. Soil Sci. Soc. Am. J. 1985, 49, 1264-1270. [CrossRef] 